OPEN ACCESS

Edited and Reviewed by: Danielle Way, University of Western Ontario, Canada

*Correspondence: Mark A. Adams maadams@swin.edu.au

Received: 08 May 2018 Accepted: 25 June 2018 Published: 10 July 2018

Citation:

Adams MA and Pfautsch S (2018) Grand Challenges: Forests and Global Change. Front. For. Glob. Change 1:1. doi: 10.3389/ffgc.2018.00001

\section{Grand Challenges: Forests and Global Change}

\author{
Mark A. Adams ${ }^{1 *}$ and Sebastian Pfautsch ${ }^{2}$ \\ ${ }^{1}$ Swinburne University of Technology, Hawthorn, VIC, Australia, ${ }^{2}$ School of Social Science and Psychology, Western Sydney \\ University, Penrith, NSW, Australia
}

Keywords: forest management, conservation, forest science, global change, forest growth, forestry

\section{INTRODUCTION AND CONTEXT}

In seeking to identify challenges for forest research, we take an over-the-horizon view. The obvious context for such a view is the current state of the world's forests, especially in relation to their management and conservation (in the broadest sense of the word). Three contextual factors stand out: (1) Changes in area and status (as determined by legislation and policy) of native forests. (2) Population growth and urbanization (and implications for use of energy and materials and competition with food production). (3) Changes in area and productivity of industrial plantations.

For the first of these, we note that in 2015, forests covered 4 billion hectares of the globe (FAO, 2016). National policies and legislation designed to protect forest values (e.g., often described as Sustainable Forest Management-SFM) covered 70\% of this area in 2010 and 99\% in 2015. Best practice SFM (by some definitions) is now applied to $\sim 1.1$ billion hectares (see also MacDicken et al., 2015). The area under international certification schemes for SFM increased 30-fold from 14 million hectares in 2000 to 438 million hectares in 2014. Conservation of biodiversity is now the primary goal of $16 \%$ of the world's forested lands and $27 \%$ of tropical forests (See Figure 1). Nonetheless, the world is still losing forest area-largely to clearing for food production - though at a much slower rate compared to, say, 1990-2000 (FAO, 2016). Poor tropical countries provide by far the greatest proportion of the net loss of natural forests (Sloan and Sayer, 2015).

The second significant context is the predicted rise in the global population from $\sim 7.5$ billion to more than 9.5 billion people by 2050 (United Nations, 2014). This alone will generate unprecedented pressure on goods and services provided by forests. It will also compound the issues associated with loss of native forests as a result of conversion to agricultural land in the tropics, mostly in Africa, South America and subtropical Asia (FAO JRC, 2012). Recognition has been slow of the compounding effects on forests of population growth and resultant demand for wood, water, carbon sequestration etc., and has come largely in the form of national and international policies and programs designed to reduce losses of native forests (FAO, 2016).

Less well recognized is the trend of urbanization. Today, urban areas occupy $<5 \%$ of the terrestrial surface, but by 2030 this area will have doubled (Fragkias et al., 2013). Globally, economic development is bringing continued and even accelerating urbanization, accompanied by declining rural populations (Figure 2; United Nations, 2014). Unarguably, the Anthropocene is also "the age of the city" (sensu Scheuer et al., 2016), with 4 billion people living in metropolitan areas in 2014, and as many as 6.5 billion will do so by 2050 . 


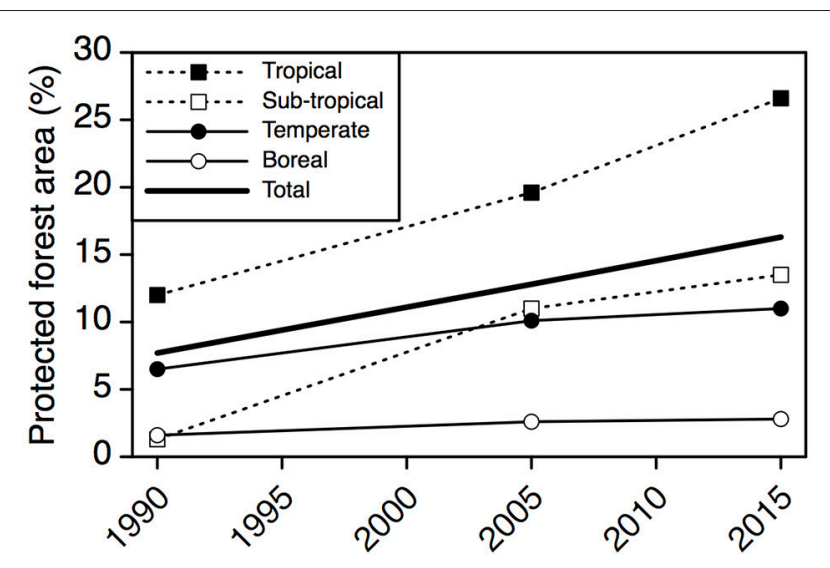

FIGURE 1 | Development of protected forest area in different climate domains. Data from Global Forest Resources Assessment (FAO, 2015).

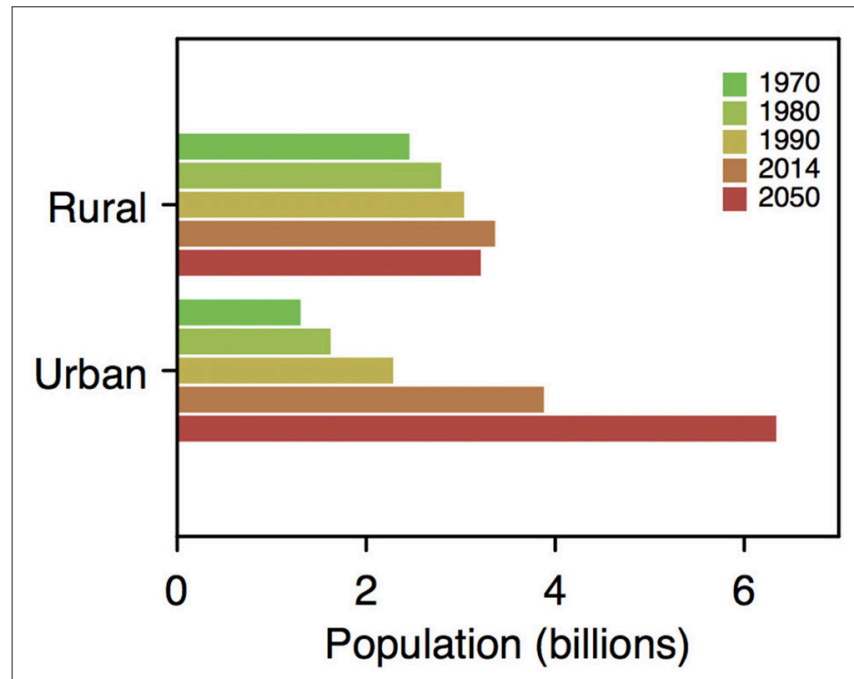

FIGURE 2 | Observed and predicted development of global population from 1970 to 2050, separated in rural and urban clusters. Redrawn from United Nations (2014).

The extraordinary change in "where people live," has followed rapid improvements in efficiency of primary production, such that far fewer people are now required per unit production in well-developed countries. In Australia for example, by 2011 there were $40 \%$ less farmers than there had been just 30 years earlier. Employment in wood and wood products sector fell from around 85,000 jobs to 64,000 jobs between 2006 and 2016 (Australian Bureau of Statistics). This is a pattern throughout the developed world-declining proportions of populations are involved in primary production.

The sheer scale of urbanization is resulting in direct losses of biodiversity, spread of invasive flora and fauna, and displacement of agriculture (see von der Lippe et al., 2005; Gibson et al., 2011; Newbold et al., 2014). Urbanisation also leads, indirectly, to poor understanding of forests through lack of first-hand experience (excluding, perhaps, the negative impacts of wildfires). So profound is the urbanization effect that the "concept, vision, values and utility of forests and the countryside today are largely defined by people living and working in cities" (Westin et al., 2017). It is not surprising that regions with greatest rates of net loss of forest are those that also have the fastest rates of urbanization (Scheuer et al., 2016).

The last of our three notable contexts is (area and productivity of) industrial plantations. Wood supply from plantations now meets around one third of global demand for wood and wood products. The balance comes from native forests. However, on present indications, plantations will not meet future demand (Figure 3, INDUFOR, 2012) unless there are continued efforts to increase their area and productivity. While the area of plantations of both softwood and hardwood species increased by $50 \%$ between 1990 and 2015 (Payn et al., 2015), sustaining such a rate of increase will present a major challenge given competing demand for land for food production. It is telling that forest industry and anti-logging activists are agreed that the rising demand for wood and fiber is the key driver of conflicts over the future of native forests.

\section{GRAND CHALLENGE(S)}

The described contextual setting-including embedded urban concerns about forest conservation and the relationship of forests to the "state" of the atmosphere (e.g., Mahli and Phillips, 2004)_is a potent reminder that the Anthropocene is well and truly upon us. When the direct and indirect effects on forests of population growth and urbanization are added to the respective direct and indirect effects of rising atmospheric $\left[\mathrm{CO}_{2}\right]$, there is a rich field of research needs and opportunities. In the following sections, a few are given some prominence. That is not to say that other needs and opportunities aren't worthy of being highlighted (for example, ensuring the sustainable growth and regrowth of native forests globally might be one obvious choice; another would be the effects of changes in the chemical composition of the atmosphere, and of changes in climate, on forests). Nonetheless, we have selected three fields that we believe are ready for significant advances in scientific knowledge and understanding to underpin future policies and practices. We also believe these are fields where research offers solutions, rather than just highlighting problems, and will thus draw public support and help raise the profile of forest science.

\section{Production From Planted Forests}

While it may seem somewhat "twentieth century," there is a very real and significant challenge to maintain and increase yield from planted forests. As described above, in addition to trying to slow rising demand for wood and wood products, the world needs to produce more from areas devoted to planted forests in order to reduce pressure on native forests. A good example of the issue-and of recent research designed to help meet demand-is contained in Binkley et al (2017). Issues such as the sustainability of nutrient supplies for second and third and fourth generation plantations, and matching sites to species (the familiar G x E interaction), will be front and center. These issues 


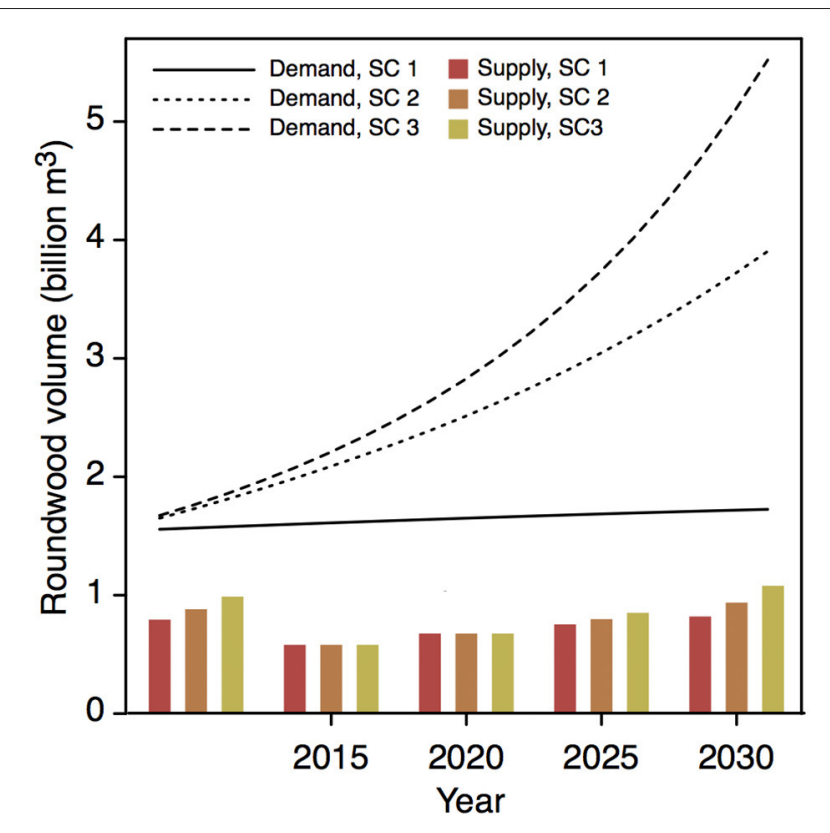

FIGURE 3 | Global supply (bars) and demand (lines) of roundwood (Data from INDUFOR, 2012). Currently (2015), roundwood supply from planted forests meets around one third of global industrial demand. On the supply side, none of the modeled scenarios (SC 1-SC 3) predict plantations can provide more than 1 billion $\mathrm{m}^{3}$ by 2030 . On the demand side, all three modeled scenarios (SC 1-SC 3) predict that rising populations and urbanization will create demand of between 1.5 and 4.5 billion $\mathrm{m}^{3}$ by 2030 . The worst case scenario is thus that there will be a rapidly increasing pressure to meet demand by cutting native forests. will be greatest for old soils in tropical and sub-tropical climates, and for plantations on sandy soils. Competing uses of landcompetition between food and fiber-will be a significant part of the challenge. Historically, food production has displaced native forests, and planted forests are typically confined to poorer sites than are used for agriculture. National and international policies will be needed to limit pressure on native forests, if that historic pattern continues. Research into plantation productivity will be a significant aspect of such policy interventions.

\section{Fire}

Fires and forests are virtually synonymous. From the wet tropics to the boreal north, fire is a ubiquitous part of forests. Now, owing to their human impacts, wildfires in the boreal forests (e.g., Kelly et al., 2013), in tropical forests (e.g., Aragão et al, 2018), and everywhere in between, are drawing public attention owing to their frequency and severity. Recent increases in fire frequency and severity are forcing significant re-thinking of the roles of episodic events in global carbon budgets. As has been noted (see Adams, 2013; Williams, 2013), poorly based policies and practices throughout the world led to unprecedented increases in fuel loads over the post-war period, with the problem escalating rapidly during the latter parts of the twentieth century and early twenty first century. Policies and practices in some countries were more alert to the issue from the end of WWII till the 1980s, at least.
However population growth, urbanization and changing climates have since swamped efforts to increase mitigation, and favored crisis management. "Urbanization" is also reflected in ample funding for short-term, "crisis" research. When more people understood forests it was an easier task to argue to funding for long-term solutions.

A major challenge for forest fire research will be to develop better knowledge of wildfire mitigation. Already, costs (and losses) of wildfires are so great as to make puny by comparison, investments in mitigation. Using the USA as an example, by 2017 the direct costs of suppression of forest fires had reached almost \$3B annually (National Interagency Fire Centre, 2018). That figure dwarfs the annual expenditure on mitigation actions like fuel management. More telling is "total cost + loss" analysis, as conducted by the US Department of Commerce (Thomas et al., 2017). They estimated total annual costs (i.e. including indirect costs of wildfire suppression) were in the range $\$ 8$ Billion to $\$ 63 \mathrm{~B}$. Staggeringly, the losses (direct and indirect) due to wildfire were in the range $\$ 64 \mathrm{~B}-\$ 285 \mathrm{~B}$. While the USA may be an extreme example of economic development and urbanization, nearly every country with forests is struggling with these same issue(s). Total cost + loss assessments would be stark for dozens of countries with far less economic capacity than the USA, and at least equally bad "fire problems."

To further place these extraordinary numbers in a worthwhile context, it is worth noting that in 2016, expenditure on research into wildland fire management by the US Forest Service was just $\$ 20$ Million! Order-of-magnitude increases in R\&D spending are now critically needed worldwide. Without such a step increase, regional and national economies are going to suffer more than they already do.

\section{Water}

Drought responses of forests have been a strong trend in forest research literature in the past decade. Led by concerns about forest growth and productivity and carbon storage being affected by changing climates in tropical regions (e.g., Gatti et al., 2014; Doughty et al., 2015), the issues of water yield for forest-dominated landscapes are only beginning to play out. These issues are significant worldwide, including areas such as Europe (e.g., Ellison et al., 2012, 2017) where water yield from forests has long been a given. Recent research has highlighted the role of forests on both the supply and demand side of hydrologic budgets. Water shortages for urban populations (e.g., the 2018 water crisis at Cape Town, South Africa) have drawn a spotlight to this issue in some water-limited countries (e.g., Bennett and Kruger, 2015).

At the organismal scale, the role of plants in transferring water from the soil to the atmosphere has fascinated scientists for hundreds of years. Perhaps most famously described for trees by Leonardo da Vinci more than 500 years ago (see Minamino and Tateno, 2014), the role of structure in water transportone of the most important of all tree functions-remains a research field that engages hundreds of forest scientists (see Pfautsch, 2016; Landsberg et al., 2017; Venturas et al., 2017, for just three examples of many recent reviews and updates). 
As long-lived organisms, the major structural parts of trees change only slowly over years to decades, while other partsleaves, twigs and fine roots-can vary enormously as trees grow and age, and also much more quickly reflect changes in the environment. Establishing the role of trees in hydrological cycles involves measurements that now span spatial scales over at least ten orders of magnitude, and over a similar range in temporal scales. The subject of trees and water will continue to be a dominant research theme, with an acute challenge being incorporating new knowledge at the cellular and molecular scales into stand- and catchment-scale understandings and models.

\section{Summary}

While drawing attention to just three 'grand challenges' for forest research in the twenty first century (and we have noted that there are many more), we have still traversed from the tropics to the poles, and drawn on clearly global contextual information and issues. Without question, people will be central to the future of forests, but perhaps in a different way to how they have been in the past. Keeping increasingly urbanized populations engaged with forests will require more than free access to a picnic area in a National Park. Equally, forests are not museums, but are dynamic, life-support systems for the planet. Developing

\section{REFERENCES}

Adams, M. A. (2013). Mega-fires, tipping points and ecosystem services: managing forests and woodlands in an uncertain future. For. Ecol. Manage. 294, 250-261. doi: 10.1016/j.foreco.2012.11.039

Aragão, L. E. O. C., Anderson, L. O., Fonseca, M.G., Rosan, T. M., Vedovato, L. B., Wagner, F. H., et al., (2018). 21st Century drought-related fires counteract the decline of Amazon deforestation carbon emissions. Nat. Commun. 9:536. doi: 10.1038/s41467-017-02771-y

Bennett, B. M., and Kruger, F. J. (2015). Forestry and Water Conservation in South Africa: History, Science and Policy. Acton ACT 2601, ANU Press, The Australian National University.

Binkley, D., Campoe, O. C., Alvares, C., Carneiro, R. L., Cegatta, Í., LuizStape, J., et al., (2017). The interactions of climate, spacing and genetics on clonal Eucalyptus plantations across Brazil and Uruguay. For. Ecol. Manage. 405, 271-283. doi: 10.1016/j.foreco.2017.09.050

Doughty, C. E., Metcalfe, D. B., Girardin, C. A., Amézquita, F. F., Cabrera, D. G., Huasco, W. H., et al (2015). Drought impact on forest carbon dynamics and fluxes in Amazonia. Nature 519, 78-82. doi: 10.1038/nature 14213

Ellison, D., Morris, C. E., Locatelli, B., Sheil, D., Cohen, J., Murdiyarso, D., et al., (2017). Trees, forests and water: Cool insights for a hot world. Global Environ. Chang. 43, 51-61. doi: 10.1016/j.gloenvcha.2017.01.002

Ellison, D., Futter, M. N., and Bishop, K. (2012). On the forest cover-water yield debate: from demand- to supply-side thinking. Glob. Chang. Biol. 18, 806-820. doi: 10.1111/j.1365-2486.2011.02589.x

FAO and JRC (2012). Global forest land-use change 1990-2005. FAO Forestry Paper No.169. The Food and Agricultural Organization of the United Nations with the E.U. Joint Research Centre, Rome.

FAO (2015). Global Forest Resources Assessment 2015. FAO Forestry Paper No. 1. UN Food and Agriculture Organization, Rome.

FAO (2016). State of the World's Forests 2016. Forests and agriculture: land-use challenges and opportunities. The Food and Agricultural Organization of the United Nations, Rome.

Fragkias, M., Güneralp, B., Seto, K.C., Goodness J., (2013). “A synthesis of global urbanization projections," in Urbanization, Biodiversity and Ecosystem Services: predictive power for the many forest-provided, yet humancritical products, processes and services, is a challenge worthy of the twenty first century.

\section{AVAILABILITY OF DATA AND MATERIALS}

All data and materials used in this review are publicly available through the cited sources.

\section{AUTHOR CONTRIBUTIONS}

MA and SP contributed equally to the ideas and content. SP prepared all the figures. Some of this material was presented in September 2017 at the Global Forest Biodiversity Conference, Beijing, China.

\section{FUNDING}

We thank an anonymous donor for financial support for SP.

\section{ACKNOWLEDGMENTS}

We thank many colleagues for productive discussions over many years.

Challenges and Opportunities, eds T. Elmqvist, M. Fragkias, J. Goodness, B. Güneralp, P. J. Marcotullio, R. I. McDonald, S. Parnell, M. Schewenius, M. Sendstad, K. C. Seto and C. Wilkinson (Dordrecht: Springer), 409-435.

Gatti, L. V., Gloor, M., Miller, J. B., Doughty, C. E., Malhi, Y., Domingues, L. G., et al. (2014). Drought sensitivity of Amazonian carbon balance revealed by atmospheric measurements. Nature 506, 76-80. doi: 10.1038/nature12957

Gibson, L., Lee, T. M., Koh, L. P., Brook, B. W., Gardner, T. A., Barlow, J., et al. (2011). Primary forests are irreplaceable for sustaining tropical biodiversity. Nature 478, 378-383. doi: 10.1038/nature10425

INDUFOR (2012). Strategic Review of the Future of Forest Plantations. A12-06869, ID 11914, Helsinki, 121.

Kelly, R., Chipman, M. L., Higuera, P. E., Stefanova, I., Brubaker, L. B., Hu, F. S., et al. (2013). Recent burning of boreal forests exceeds fire regime limits of the past 10,000 years. Proc. Natl. Acad. Sci. U.S.A. 110, 13055-13060. doi: 10.1073/pnas.1305069110

Landsberg, J., Waring, R., and Ryan, M. (2017). Water relations in tree physiology: where to from here? Tree Physiol. 37, 18-32. doi: 10.1093/treephys/tpw102

MacDicken, K. G., Sola, P., Hall, J. E., Sabogal, C., Tadoum, M., de Wasseige, C., et al. (2015). Global progress towards forest sustainable management. For. Ecol. Manage. 325, 47-56. doi: 10.1016/j.foreco.2015.02.005

Mahli, Y., and Phillips, O. L. (2004). Tropical forests and global atmospheric change: a synthesis. Philos. Trans. R. Soc.Lon. B Bio. Sci. 359, 549-555. doi: $10.1098 /$ rstb.2003.1449

Minamino, R., and Tateno, M. (2014). Tree branching: leonardo da vinci's rule versus biomechanical models. PLoS ONE 9:e93535. doi: 10.1371/journal.pone.0093535

National Interagency Fire Centre (2018). Federal Firefighting Costs (Suppression Only). Available oline at: https://www.nifc.gov/fireInfo/fireInfo_documents/ SuppCosts.pdf.

Newbold, T., Hudson, L. N., Phillips, H. R., Hill, S. L., Contu, S., Lysenko, I.,et al. (2014). A global model of the response of tropical and sub-tropical forest biodiversity to anthropogenic pressures. Proc. Biol. Sci. 218:20141371. doi: 10.1098/rspb.2014.1371

Payn, T., Carnus, J. M.,Smith, P. F., Kimberley, M., Kollert, W., Liu, S.,et al. (2015). Changes in planted forests and future global implications. For. Ecol. Manage. 352, 57-67. doi: 10.1016/j.foreco.2015.06.021 
Pfautsch, S. (2016). Hydraulic anatomy and function of trees-basics and critical developments. Curr. Forestry Rep. 2, 236-248. doi: 10.1007/s40725-016-0046-8

Scheuer, S., Haase, D., and Volk, M. (2016). On the nexus of the spatial dynamics of global urbanization and the Age of the City. PLoS ONE 11:e0160471. doi: 10.1371 /journal.pone.0160471.

Sloan, S., and Sayer, J. A. (2015). Forest Resources Assessment of 2015 shows positive global trends but forest loss and degradation persists in poor tropical countries. For. Ecol. Manage. 352, 134-145. doi: 10.1016/j.foreco.2015.06.013

Thomas, D. S., Butry, D. T., Gilbert, S. W., Webb, D. H., and Fung, J. F. (2017). The Costs and Losses of Wildfires: A Literature Review. NIST Special Publication 1215. National Institute of Standards and Technology, US Dept of Commerce.

United Nations (2014). World Population Prospects: The 2014 Revision. New York, NY: Population Division, Department of Economic and Social Affairs, United Nations.

Venturas, M. D., Sperry, J. S., and Hacke, U. G. (2017). Plant xylem hydraulics: What we understand, current research, and future challenges. J. Integr. Plant Biol. 59, 356-389. doi: 10.1111/jipb.12534

von der Lippe, M., Säumel, I., and Kowarik, I. (2005). Cities as drivers for biological invasions - The role of urban climate and traffic. Die Erde 136, 123-143.
Westin, K., Eriksson ,L., Lidestav, G., Karppinen, H., Haugen, K., Annika, N., et al. (2017). "Individual forest owners in context," in Globalisation and Change in Forest Ownership and Forest Use - Natural Resource Management in Transition, ed Keskitalo ECH (London: Macmillan Publishers), $57-95$.

Williams, J. (2013). Exploring the onset of high-impact mega-fires through a forest land management prism. For. Ecol. Manage. 294, 4-10. doi: $10.1016 /$ j.foreco.2012.06.030

Conflict of Interest Statement: The authors declare that the research was conducted in the absence of any commercial or financial relationships that could be construed as a potential conflict of interest.

Copyright $\odot 2018$ Adams and Pfautsch. This is an open-access article distributed under the terms of the Creative Commons Attribution License (CC BY). The use, distribution or reproduction in other forums is permitted, provided the original author(s) and the copyright owner(s) are credited and that the original publication in this journal is cited, in accordance with accepted academic practice. No use, distribution or reproduction is permitted which does not comply with these terms. 